\title{
QUANTIFICATION AND EVALUATION OF SOIL ORGANIC CARBON AND ITS FRACTIONS: CASE STUDY FROM THE CLASSICAL KARST, SW SLOVENIA
}

\author{
KVANTIFIKACIJA IN VREDNOTENJE ORGANSKEGA OGLJIKA \\ IN NJEGOVIH FRAKCIJ V TLEH: \\ PRIMER S KLASIČNEGA KRASA, JZ SLOVENIJA
}

\author{
Hui YANG ${ }^{1,2}$, Mitja PRELOVŠEK ${ }^{3}$, Fen HUANG $^{1,2}$, Chunlai ZHANG ${ }^{1,2}$, \\ Jianhua $\mathrm{CAO}^{1,2 *} \&$ Nataša RAVBAR ${ }^{3}$
}

\begin{abstract}
UDC 551.44:631.445.6(497.47)
Hui Yang, Mitja Prelovšek, Fen Huang, Chunlai Zhang, Jianhua Cao \& Nataša Ravbar: Quantification and evaluation of soil organic carbon and its fractions: case study from the Classical Karst, SW Slovenia

Soil organic carbon (SOC) is a critical measure of soil organic matter (SOM) content. SOM plays a vital role in ecosystem services, soil fertility, soil water retention capacity, and carbon cycling. SOC can be partitioned into various carbon fractions, which exhibit diverse stability and chemical compositions that are influenced variably by lithology as well as biological and climatic processes. A better understanding of SOC and the influence of different bedrock types on carbon fractions could facilitate the evaluation of the fate and stability of SOC. The present study is focused on the concentrations and characteristics of different SOC fractions (e.g., Labile organic carbon, LOC; Recalcitrant organic carbon, ROC; Calcium-bound organic carbon, Ca-SOC; Iron/aluminium-bound organic carbon, Fe/AlSOC) in forest soils associated with different bedrock lithology under similar climate conditions in the centre of the 'Classical Karst', and evaluates influence of the geological environment on SOC. SOC and SOC fraction concentrations decreased with an increase in depth in all profiles, indicating stabilized soil profiles. SOC values $\left(9.7-45.5 \mathrm{~g} \cdot \mathrm{kg}^{-1}\right)$ were consistent with the findings of other studies on soils in the region. ROC and Fe/AlSOC (51.5-65.8 \% and 68.0-73.3\%, respectively) were the major SOC fractions, while Ca-SOC accounted for a considerably lower proportion (6.4-7.4\%) of the SOC contents. Key factors
\end{abstract}

\begin{abstract}
Izvleček
UDK 551.44:631.445.6(497.47)

Hui Yang, Mitja Prelovšek, Fen Huang, Chunlai Zhang, Jianhua Cao \& Nataša Ravbar: Kvantifikacija in vrednotenje organskega ogljika in njegovih frakcij v tleh: primer s Klasičnega Krasa, JZ Slovenija

$\mathrm{Z}$ meritvami organskega ogljika $\mathrm{v}$ prsteh (SOC) izražamo vsebnost organskih snovi v prsteh (SOM). SOM igra ključno vlogo pri ekosistemskih storitvah, rodovitnosti, zmogljivosti zadrževanja vode in kroženju ogljika. SOC lahko razdelimo na različne ogljikove frakcije, ki kažejo različno stabilnost in kemično sestavo, na katero različno vplivajo litološka zgradba, biološki in podnebni procesi. Boljše razumevanje SOC in vpliv različnih vrst matične podlage na ogljikove frakcije bi lahko olajšala oceno stabilnosti SOC. Ta študija preučuje koncentracije in dinamiko različnih frakcij SOC (npr. labilni organski ogljik, LOC; rekalcitrantni organski ogljik, ROC; organski ogljik, vezan na kalcij; organski ogljik, vezan na železo/aluminij, Fe/Al-SOC) v gozdnih prsteh in povezanost $\mathrm{z}$ različno litološko zgradbo v podobnih podnebnih razmerah. Prostorsko se študija osredotoča na območje klasičnega krasa. Koncentracija SOC in njegove frakcije so se $\mathrm{z}$ naraščajočo globino $\mathrm{v}$ vseh profilih zmanjšale, kar kaže na relativno uravnotežene profile prsti. Vrednosti SOC $\left(9,7-45,5 \mathrm{~g} \cdot \mathrm{kg}^{-1}\right)$ so skladne $\mathrm{z}$ ugotovitvami drugih raziskav prsti $\mathrm{v}$ regiji. ROC in Fe/Al-SOC (51,5-65,8 \% oziroma 68,0-73,3\%) sta bili glavni komponenti SOC, medtem ko je za Ca-SOC značilen bistveno nižji delež $(6,4-7,4 \%)$. Ključna dejavnika, ki vplivata na vsebnost SOC, sta vsebnost kalcita (izražen kot kalcijev oksid) in gline; tadva s
\end{abstract}

\footnotetext{
${ }^{1}$ Key Laboratory of Karst Dynamics, MLR/Guangxi, Institute of Karst Geology, CAGS, Guilin 541004, China

${ }^{2}$ International Research Centre on Karst, UNESCO, Guilin 541004, China

${ }^{3}$ Karst Research Institute, Research Centre of the Slovenian Academy of Sciences and Arts, Postojna 6230, Slovenia

* Corresponding author
}

Received/Prejeto: 07.03.2019

DOI: https://doi.org/10.3986/ac.v48i3.7305 
influencing SOC contents were calcite (expressed as calcium oxide) and clay contents, which represent mineral complexes stabilizing SOC. Overall $\mathrm{Fe}_{2} \mathrm{O}_{3}$ and $\mathrm{Al}_{2} \mathrm{O}_{3}$ concentration did not explain differences in SOC nor its fractions, potentially due to the importance of chemical/mineral forms of Fe- and Al-related minerals (reactivity). Soils on carbonate rocks, which are richer in clay and $\mathrm{CaO}$, had $6.35 \mathrm{~g} \cdot \mathrm{kg}^{-1}$ (28 percentage points) higher concentrations of SOC average when compared with soils on siliciclastic rock, due to higher concentrations of stabilized SOC fractions. The results demonstrate that bedrock lithology and pedogenesis are key factors influencing SOM stabilization.

Key words: karst soil; soil organic carbon; labile organic carbon; recalcitrant organic carbon; calcium-bound organic carbon; iron/aluminium-bound organic carbon.
SOC tvorita mineralne komplekse, ki stabilizirajo SOC. Vrednosti $\mathrm{Fe}_{2} \mathrm{O}_{3}$ in $\mathrm{Al}_{2} \mathrm{O}_{3}$ ne pojasnjujejo razlik SOC niti njegovih frakcij, kar je lahko posledica različnega vpliva kemičnih/mineralnih oblik železovih oz. aluminijevih spojin na reaktivnost. Prsti na karbonatnih kamninah, ki so bogatejše z delci velikosti glin in $\mathrm{CaO}$, so imele zaradi višjih koncentracij stabiliziranih SOC frakcij za $6,35 \mathrm{~g} \cdot \mathrm{kg}^{-1}$ (28 odstotnih točk) višje povprečne vrednosti SOC v primerjavi prstmi na siliciklastičnih (flišnih) kamninah. Rezultati kažejo, da sta osnovna dejavnika, ki vplivata na stabilizacijo SOM, litološka zgradba in pedogeneza.

Ključne besede: kraške prsti, organski ogljik v tleh, labilni organski ogljik, rekalcitrantni organski ogljik, organski ogljik, vezan na kalcij, organski ogljik, vezan na železo/aluminij.

\section{INTRODUCTION}

Soil organic matter (SOM) plays an essential role in the maintenance of soil quality and ecosystem functionality (Benbi et al. 2015). In addition, SOM is also an integral element of the carbon cycle and; therefore, critical for atmospheric $\mathrm{CO}_{2}$ sequestration (Houghton et al. 1998; Lal 2004; Xiao et al. 2017). Since the quantification of SOM directly is challenging, soil organic carbon (SOC) is measured and reported as an alternative.

SOM encompasses diverse substances/forms that exhibit varied mechanisms of stabilization and turnover times (Cai et al. 2016; Xu et al. 2016). Based on chemical stability, SOC may be divided into labile organic carbon (LOC), semi-labile organic (sLOC), and recalcitrant organic carbon (ROC) fraction where different environmental conditions influence conversion from one fraction to another (Parton et al. 1987; Rovira \& Vallejo 2002). Among the soil organic matter fractions, the LOC fraction (e.g., light fraction and particulate organic carbon) accounts for a relatively minor proportion of total SOC since it is easily decomposed and is highly sensitive to climatic or local environmental conditions (Purakayastha et al. 2007; Schmidt et al. 2011).

Clay minerals and iron oxides, in addition to other oxides, play key roles in the preservation of SOC (Wang et al. 2013). In addition, the combination of calciumbound soil organic carbon (Ca-SO C) and iron/aluminium-bound soil organic carbon (Fe/Al-SOC) constitutes a key route of soil organic carbon stabilization (Xu et al. 1999). However, while Ca-SOC is a relatively weak (outersphere) complex, Fe/Al-SOC represents a strong (innersphere) complex. Similarly, iron/aluminium-bound humus exhibits greater complex affinities when compared with calcium-bound humus (Xu et al. 1999).

Soil carbon storage and release dynamics vary regionally and are mainly under the influence of climatic and geological conditions, in addition to land-use types (Wang \& Hsieh 2002; Ogrinc et al. 2016). Soil parent material, particularly, could influence ecosystem (vegetation and soil) functioning and, in turn, influence SOM stock in soils considerably (Barré et al. 2017). Changes in SOC fractions could serve as early indicators of changes in total SOC (Banger et al. 2009). Since changes in SOC fractions could influence both nutrient supply and soil carbon sequestration, it is necessary to fractionate and quantify the labile and recalcitrant fractions, which would facilitate our understanding of factors influencing SOC kinetics (Belay-Tedla et al. 2009; Liu et al. 2017).

Despite karst terrain accounting for approximately $15 \%$ of the dry ice-free land globally (Ford \& Williams 2007; Chen et al. 2017) with considerable carbon sequestration potential (Gombert 2002; Liu et al. 2010), studies on SOC contents and, particularly, their fractions in karst soils, have been but marginally studied. Consequently, SOC stock dynamics in karst areas globally are poorly understood (Ahmed et al. 2012). In addition, since the decomposition of SOC influences $\mathrm{CO}_{2}$ concentration in the soil and decomposition is linked directly to carbonate rock dissolution intensity, SOC plays an additional key role in $\mathrm{CO}_{2}$ sequestration (Cao et al. 2011). Therefore, such studies have global importance.

The aim of the present study was to evaluate SOC and its fractions in a karst and non-karst environment. The major objectives included (1) quantification of SOC and evaluation of SOC fractions in soils developed on carbonate rocks and (2) comparison with SOC quantities and fractions in soils developed on non-carbonate (mainly siliciclastic) rocks. Both soil types examined in the present study developed under similar climatic and environmental conditions. 


\section{STUDY AREA}

The study area is located in the vicinity of Postojna, which lies in the Classical Karst (NW Dinaric karst) region in SW Slovenia. The area comprises gentle slopes of the Javorniki Mountain (reaching up to $1,268 \mathrm{~m}$ a.s.l.) and the levelled surface above the well-known underground caves of Postojnska Jama ( $600 \mathrm{~m}$ a.s.l.) that rise over the Pivka River Basin ( 520 m a.s.l.; Fig. 1). Lithologically, on the Javorniki Mountain, Jurassic and Cretaceous limestones prevail (Buser et al. 1967); they are highly karstified and, therefore, permeable, and characterized by the complete absence of surface streams. The lower lying area (the Pivka River Basin) with a dense surface river network is developed on relatively impermeable siliciclastic flysch rocks - a sequence of interbedded turbiditic sandstones and marlstones as well as conglomerates in some areas.

Ultimately the surficial Pivka River sinks underground at the lithological contact between flysch and limestone near Postojna and sustains its underground flow through the underground cave system of the Postojnska Jama.

The Pivka River basin is typically a mosaic of meadows, croplands, and forests on gentle slopes, while wetlands can be found at the bottom of the valley. Karst areas are covered predominantly by natural broadleaf deciduous forests (with some fir trees) and artificially planted pine trees, in addition to artificial spruce forests. The area above the Postojnska Jama was deforested for grazing purposes over millennia and has gradually been reforested from the $19^{\text {th }}$ Century (Kaligaric et al. 2006); however, some pastures remain and are still used for grazing.

Climatologically, the study area is located in the transition zone between the Mediterranean and Continental climate (Cfb and Dfb according to Köppen-Geiger climate classification) (Peel et al. 2007). The local humid temperate climate is characterized by an average annu- al temperature of $9.3^{\circ} \mathrm{C}$ and $1,500 \mathrm{~mm}$ of precipitation (1981-2010). The hottest and coldest months are July and January, respectively, with average monthly temperatures of $19.0^{\circ} \mathrm{C}$ and $-0.1{ }^{\circ} \mathrm{C}$, respectively. Rainfall is relatively equally distributed across the year with a peak in October $(165 \mathrm{~mm})$ and a nadir in February $(81 \mathrm{~mm})$.

According to the Slovene pedological map (Grčman et al. 2015), limestone slopes are generally characterized by Rendzinas (Rendzic Leptosol; sampling site 2; Fig. 1) while levelled limestone surfaces are usually covered by thicker Chromic Cambisols (sampling site 1). Šebela et al. (2017) classified a 1-m deep soil profile at a levelled limestone surface $1.3 \mathrm{~km}$ NNE from sampling site 1 as Chromic Lixisol. Based on our determination of insoluble residues using $10 \% \mathrm{v} / \mathrm{v} \mathrm{HCl}$ solution, insoluble residues of dissolved limestone amount to less than $1 \% \mathrm{w} / \mathrm{w}$ of the original limestone when chert layers are not taken into account. Using the same methodology, insoluble residue of one siliciclastic flysch sample from the area of Postojna represents $96 \%$ w/w of the rock. However, in the same area, flysch can be composed of breccia or conglomerate with prevailing clasts made of limestone and cemented by marl as well (Pavlovec 1981) indicating high content of carbonate. Soils deeper than $0.5 \mathrm{~m}$ are relatively rare in limestone-covered areas; they are usually associated with depressions, laterally enlarged fractures, or old denuded caves filled with insoluble sediments. Due to the long-term geomorphic evolution of the area (deposition of weathered flysch sediments along the underground Pivka River accompanied by tectonic uplift and chemical denudation of the karst surface), today, cave sediments can be found on the karst surface (Šebela \& Čar 2000) and incorporated within soil profiles. On flysch bedrock, calcite can cement siliciclastic detritus forming Eutric Cambisols (sampling sites 3 and 4).

\section{SOIL SAMPLING AND ANALYSIS}

Soils samples for the analysis of SOC, its fractions, and other basic properties were collected in July 2015. Altogether, 12 soil samples were obtained from four locations and analysed (Fig. 1).

In each soil profile, sampling started at the lowest depth and continued upwards. To minimize effect of lateral variability, about $1-2 \mathrm{~kg}$ of soil per sample was gathered horizontally at each soil depth and homogenized afterwards in lab.

Fresh soil was passed through a $2 \mathrm{~mm}$ sieve, and stones and roots were removed to improve soil homogeneity. In addition, the samples were air-dried and grinded before the measurement of the soil organic carbon fractions, basic properties, and the concentrations of nutrient elements. Basic information on the soil sampling sites is summarized in Tab. 1. Studies on SOC frequently focus on the upper $50 \mathrm{~cm}$ of soil in which organic material is concentrated and where organic matter mineralization and immobilization processes are the most active (e.g., Jones et al. 2005; Liu et al. 2014). In the present study, 
therefore, SOC concentrations and fractions were analysed in the top $50 \mathrm{~cm}$ thick soil layer and soil samples were obtained within four ranges, including the $0-10-\mathrm{cm}$ range, $10-20 \mathrm{~cm}, 20-30 \mathrm{~cm}$ and the $30-50-\mathrm{cm}$ range at each sampling site.

SOC and SOC fractions analyses were conducted in the Karst Dynamics Laboratory in Guilin, China; SOC concentrations were determined by wet oxidation based on the potassium dichromate oxidation method (Bao 2000). The following SOC fractions were analysed: LOC, ROC, Ca-SOC, and Fe/Al-SOC. The basic principle applied to determine the SOC fractions was resistance to oxidation and hydrolysis following the exposure of soil samples to acids.

When analysing LOC, we considered that oxidation using a weak $\mathrm{KMnO}_{4}$ solution could yield results similar to the results of in situ the enzymatic decomposition of labile SOM (Loginow et al. 1987); therefore, $\mathrm{KMnO}_{4}$-oxidizable carbon is considered LOC in the present study. Since some aromatic compounds and humic substances in soils may also react with $\mathrm{KMnO}_{4}$ (Wang et al. 2017), our results indicate maximum LOC concentrations. LOC was estimated using the method proposed by Blair et al. (1995). Briefly, $2 \mathrm{~g}$ of the soil samples were placed into $30-\mathrm{mL}$ centrifuge tubes with plastic screw tops and $25 \mathrm{~mL}$ of $0.333 \mathrm{M} \mathrm{KMnO}_{4}$ added to each tube. The tubes were shaken thoroughly and centrifuged for $5 \mathrm{~min}$ at 2,000 rpm (Cence H1850, Xiangyi Centrifuge Instrument Co., Ltd.). One millilitre of the supernatant was diluted at a ratio of 1:250 with deionized water. The amount of the remaining (unreacted) $\mathrm{KMnO}_{4}$ was determined based on the absorbance of the diluted samples and standards using a split-beam spectrophotometer (T6 New Century, Puxi, China) at a wavelength of $565 \mathrm{~nm}$. The difference between the initial and remaining quantities of $\mathrm{KMnO}_{4}$ were used to estimate the amount of oxidized carbon, assuming $1 \mathrm{M} \mathrm{KMnO}_{4}$ was consumed $(\mathrm{Mn}[\mathrm{VII}] \rightarrow \mathrm{Mn}[\mathrm{II}])$ in the oxidation of SOM containing $9 \mathrm{mg}$ of organic carbon. LOC was equivalent to the organic carbon oxidized by $0.333 \mathrm{M} \mathrm{KMnO}_{4}$.

ROC was calculated according to the procedure of Rovira and Vallejo (2007). One hundred milligrams of each soil sample was hydrolysed with $20 \mathrm{~mL}$ of $6 \mathrm{M} \mathrm{HCl}$ in a sealed Pyrex tube at $105^{\circ} \mathrm{C}$ for $18 \mathrm{~h}$. The hydrolysate was discarded and the non-hydrolysed residue was washed using deionized water with repeated centrifugation and decantation until the solution was colourless and the $\mathrm{pH}$ was neutral, transferred to pre-weighed vials, dried at $60{ }^{\circ} \mathrm{C}$ to a constant weight, and then analysed

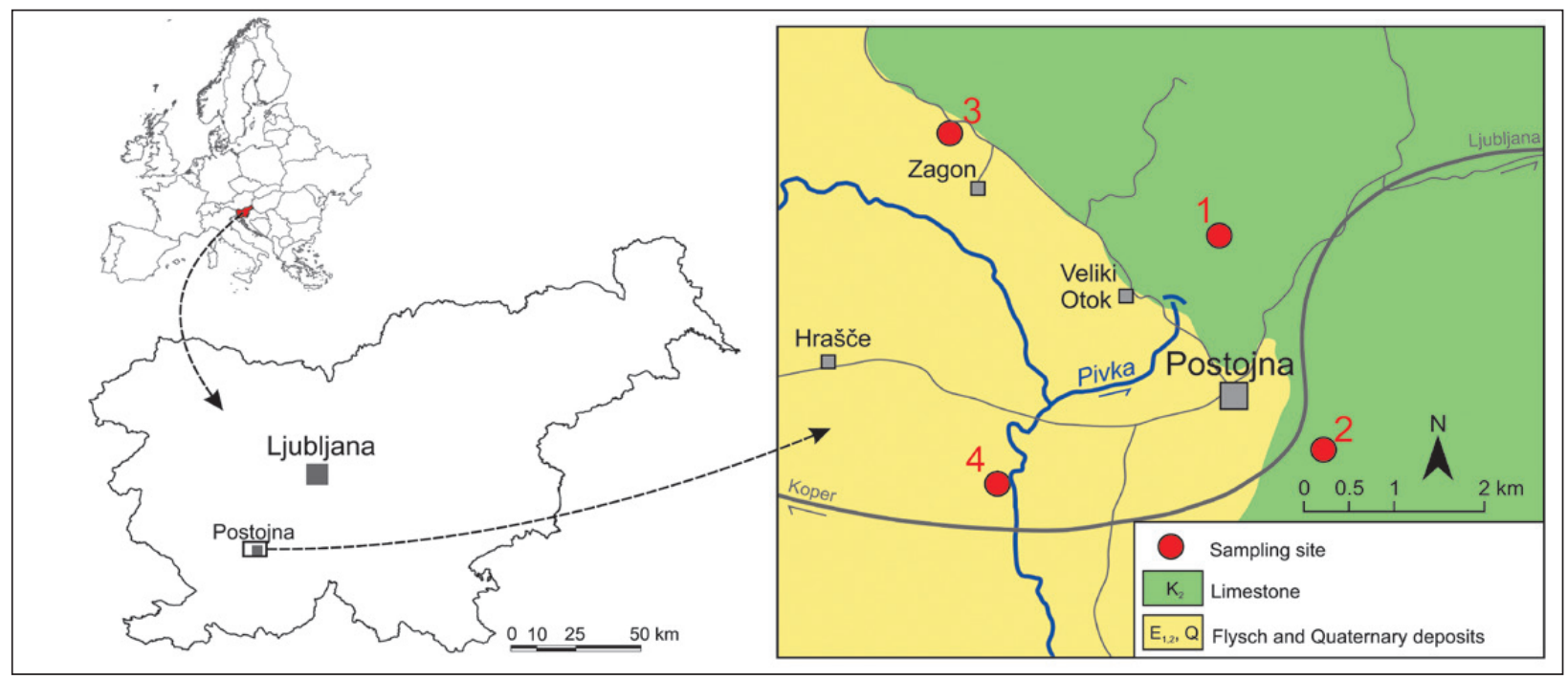

Fig. 1: Locations of the sampling sites and geological settings of the study area (geology based on Buser et al. 1967).

Tab. 1: General description of sampling sites based on bedrock, soil, and land-use types.

\begin{tabular}{cccccc}
\hline $\begin{array}{c}\text { Sampling } \\
\text { site }\end{array}$ & $\begin{array}{c}\text { Longitude } \\
\text { and latitude }\end{array}$ & $\begin{array}{c}\text { Altitude } \\
\text { (m a.s.I.) }\end{array}$ & Bedrock & Soil type & Land use \\
\hline Site 1 & $\begin{array}{l}\mathrm{N} 45^{\circ} 47^{\prime} 21.63^{\prime \prime} \\
\mathrm{E} 14^{\circ} 12^{\prime} 36.36^{\prime \prime}\end{array}$ & 635 & Limestone & Chromic Cambisols & Broadleaf Deciduous forest \\
\hline Site 2 & $\begin{array}{l}\mathrm{N} 45^{\circ} 46^{\prime} 04.22^{\prime \prime} \\
\mathrm{E} 14^{\circ} 13^{\prime} 30.86^{\prime \prime}\end{array}$ & 630 & Limestone & Rendzic Leptosol & Spruce forest \\
\hline Site 3 & $\begin{array}{l}\mathrm{N} 45^{\circ} 47^{\prime} 58.45^{\prime \prime} \\
\mathrm{E} 14^{\circ} 10^{\prime} 18.88^{\prime \prime}\end{array}$ & 550 & Siliciclastic rock & Eutric Cambisol & Mixed forest \\
\hline Site 4 & $\begin{array}{l}\mathrm{N} 45^{\circ} 45^{\prime} 50.77^{\prime \prime} \\
\mathrm{E} 14^{\circ} 10^{\prime} 44.18^{\prime \prime}\end{array}$ & 520 & Siliciclastic rock & Eutric Cambisol & Mixed forest \\
\hline
\end{tabular}


for carbon $(\mathrm{C})$ and nitrogen $(\mathrm{N})$ content using a multiN/ C3100 analyser (Analytik Jena, Germany) with $\pm 3 \%$ precision. The residual $\mathrm{C}$ was considered ROC.

Ca-SOC was estimated according to Xu et al. (1999). Briefly, $2 \mathrm{~g}$ of each soil samples was placed into a $50-\mathrm{mL}$ centrifuge tube with a plastic screw top, and $20 \mathrm{~mL}$ of $0.5 \mathrm{M} \mathrm{Na}_{2} \mathrm{SO}_{4}$ added into each vial. The tubes were shaken thoroughly and ventilated for 24 hours at room temperature $\left(\mathrm{cca} .20-25^{\circ} \mathrm{C}\right)$, centrifuged for $10 \mathrm{~min}$ at $3,000 \mathrm{rpm}$, and the supernatant transferred into a plastic bottle. The steps above were repeated several times until there was no $\mathrm{Ca}^{2+}$ in the solution, which was indicated by the absence of precipitation following the addition of a $\mathrm{K}_{2} \mathrm{CO}_{3}$ solution. The residue was washed with deionized water until the supernatant was colourless. The supernatant was transferred into a plastic bottle, centrifuged to remove the clay, transferred into a volumetric flask, and diluted with deionized water to $250 \mathrm{~mL}$. The $\mathrm{C}$ concentration was determined using a multi N/C 3100 analyser with $\pm 3 \%$ precision.

$\mathrm{Fe} / \mathrm{Al}-\mathrm{SOC}$ was analysed according to $\mathrm{Xu}$ et al. (1999): $20 \mathrm{~mL}$ of $\mathrm{NaOH}$ and $\mathrm{Na}_{4} \mathrm{P}_{2} \mathrm{O}_{7}(0.1 \mathrm{M}$ each) were added to the residue of the Ca-SOC extract. Afterwards, the mixture was left to stand overnight and centrifuged for $15 \mathrm{~min}$ at 3,000 rpm. The supernatant was decanted, the residue diluted with deionized water, and the solution centrifuged again several times until the solution was nearly colourless. All supernatants were collected, centrifuged to remove the clay, and diluted in volumetric flasks to $250 \mathrm{~mL}$. The $\mathrm{C}$ concentrations were determined using a multiN/C3100 analyser with $\pm 3 \%$ precision. The total calcium oxide $(\mathrm{CaO})$, aluminium oxide $\left(\mathrm{Al}_{2} \mathrm{O}_{3}\right)$, and iron oxide $\left(\mathrm{Fe}_{2} \mathrm{O}_{3}\right)$ concentrations in soil were determined using total X-ray fluorescence (XRF) spectroscopy. A drawback of this method is an underestimation of aluminium and iron oxides since some of them might be in amorphous or in micro-grain phase. Soil clay with fine- and medium-sized silt content (grain size $<0.053 \mathrm{~mm}$ ) was determined by wet sieve method.

Although we are aware of the limitations and drawbacks of applying statistical methods to a small number of sampling sites included in the study, we still used basic statistical approach to interpret SOC and SOC fractions.

\section{RESULTS}

Determination of the soil type is based on field observation with subsequent laboratory analyses; our determination was later compared with the Slovene pedological map (Grčman et al. 2015). Our determination coheres with the map. Analysed soil profiles are shown on Fig. 2. Numerical values of laboratory analyses are summarized in Tab. 2-6 and further studied in sub-sections of this chapter.

Tab. 2: Numerical values of laboratory analyses of clay with fine and medium-sized silt, $\mathrm{CaO}, \mathrm{Al}_{2} \mathrm{O}_{3}$ and $\mathrm{Fe}_{2} \mathrm{O}_{3}$ in \%.

\begin{tabular}{|c|c|c|c|c|c|}
\hline & Soil depth & Site 1 & Site 2 & Site 3 & Site 4 \\
\hline \multirow{5}{*}{ Clay with fine and medium-sized silt } & $0-10 \mathrm{~cm}$ & 49.21 & 67.86 & 36.85 & 6.55 \\
\hline & $10-20 \mathrm{~cm}$ & 80.54 & 84.3 & 23.05 & 26.57 \\
\hline & $20-30 \mathrm{~cm}$ & 76.2 & 87.9 & 12.46 & 34.26 \\
\hline & $30-50 \mathrm{~cm}$ & 84.54 & 86.88 & 9.46 & 36.88 \\
\hline & Average & 72.62 & 81.74 & 20.46 & 26.07 \\
\hline \multirow{5}{*}{$\mathrm{CaO}$} & $0-10 \mathrm{~cm}$ & 0.91 & 1.44 & 0.33 & 0.17 \\
\hline & $10-20 \mathrm{~cm}$ & 0.69 & 1.09 & 0.33 & 0.17 \\
\hline & $20-30 \mathrm{~cm}$ & 0.87 & 1.02 & 0.38 & 0.16 \\
\hline & $30-50 \mathrm{~cm}$ & 1.09 & 1.19 & 0.39 & 0.17 \\
\hline & Average & 0.89 & 1.19 & 0.36 & 0.17 \\
\hline \multirow{5}{*}{$\mathrm{Al}_{2} \mathrm{O}_{3}$} & $0-10 \mathrm{~cm}$ & 16.42 & 16.8 & 17.84 & 12.97 \\
\hline & $10-20 \mathrm{~cm}$ & 17.31 & 17.53 & 18.36 & 13.77 \\
\hline & $20-30 \mathrm{~cm}$ & 16.94 & 18.38 & 18.17 & 13.76 \\
\hline & $30-50 \mathrm{~cm}$ & 18.18 & 19.46 & 18.18 & 13.79 \\
\hline & Average & 17.21 & 18.04 & 18.14 & 13.57 \\
\hline \multirow{5}{*}{$\mathrm{Fe}_{2} \mathrm{O}_{3}$} & $0-10 \mathrm{~cm}$ & 6.08 & 6.47 & 6.37 & 4.91 \\
\hline & $10-20 \mathrm{~cm}$ & 6.19 & 6.62 & 6.33 & 5.17 \\
\hline & $20-30 \mathrm{~cm}$ & 5.99 & 7.02 & 6.51 & 5.27 \\
\hline & $30-50 \mathrm{~cm}$ & 6.74 & 7.78 & 6.53 & 5.04 \\
\hline & Average & 6.25 & 6.97 & 6.44 & 5.1 \\
\hline
\end{tabular}



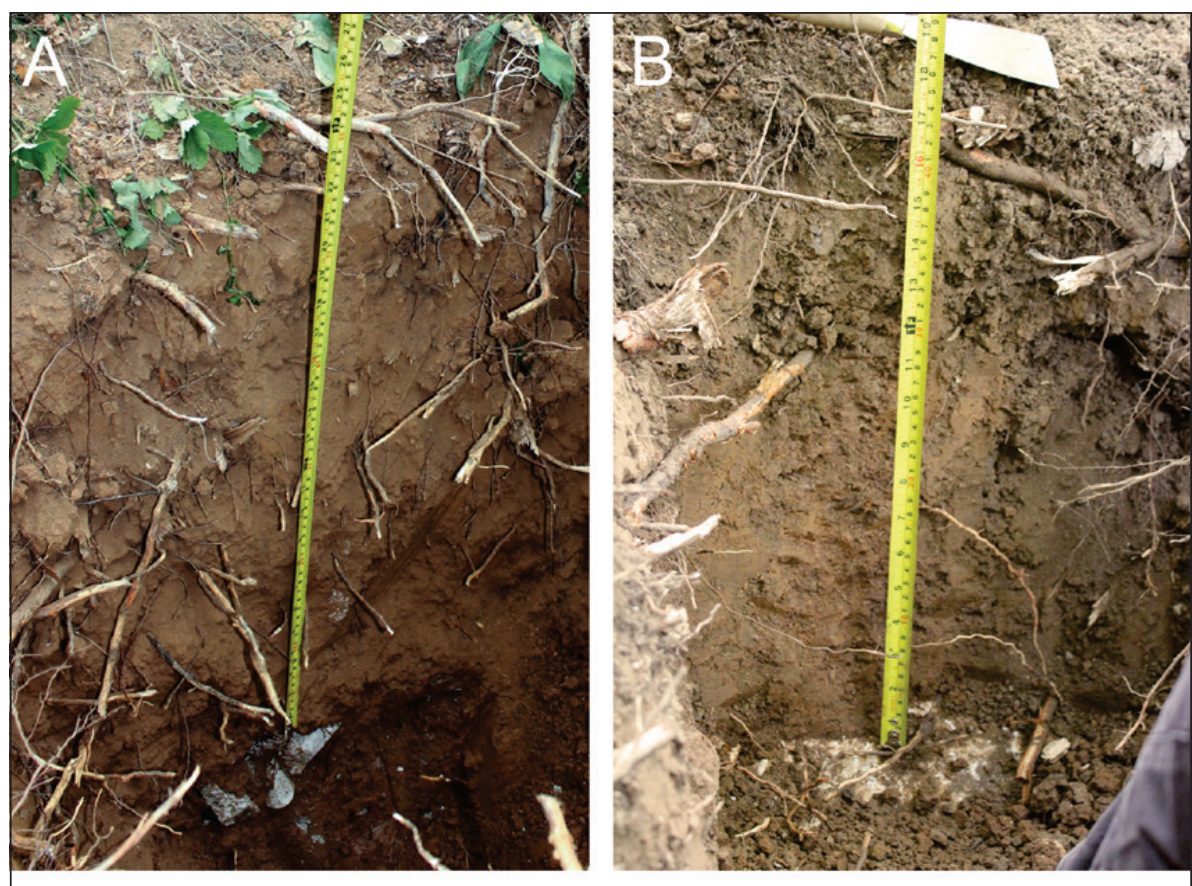

Fig. 2: Photos of the studied soil profiles: (A) Site 1, (B) Site 2, (C) Site 3, and (D) Site 4 (Photo: Hui Y., Ravbar N.).
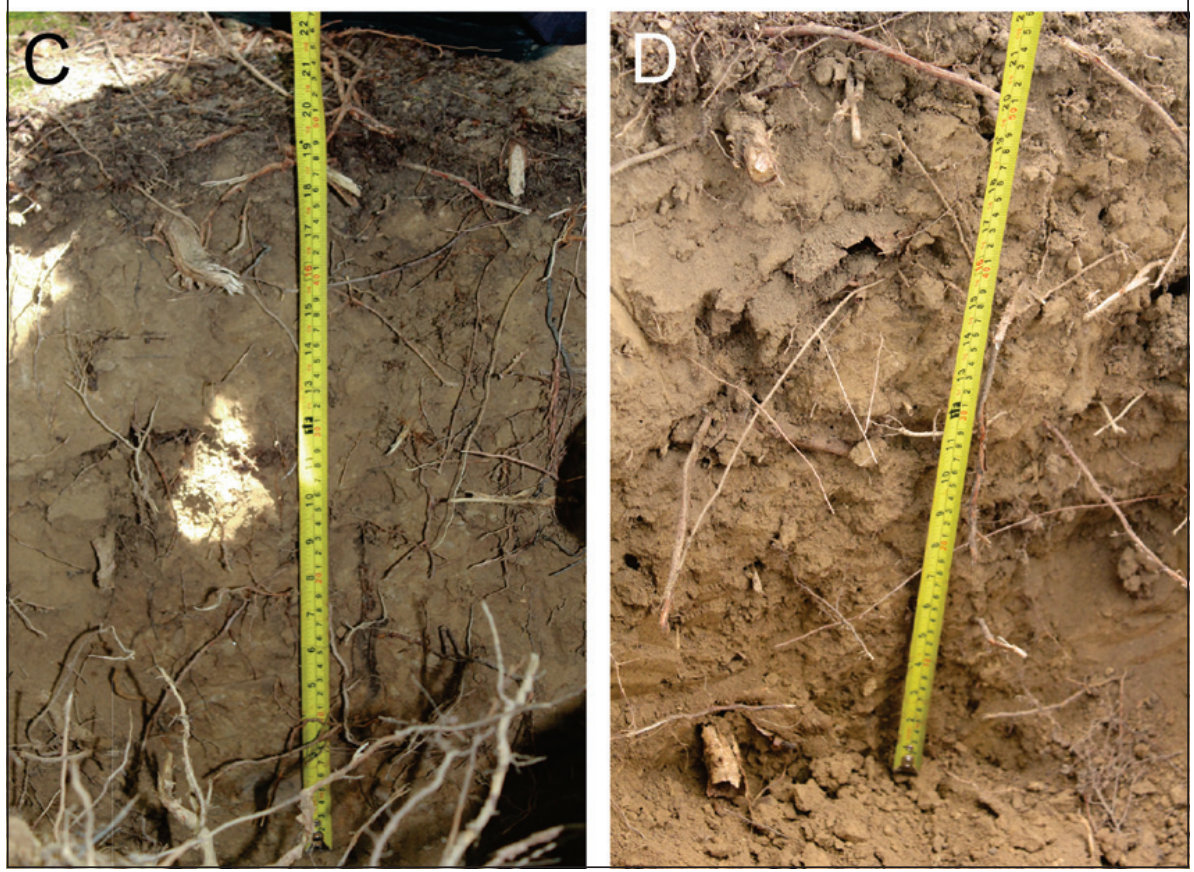

Tab. 3: Vertical distribution of SOC values based on individual concentrations in sampled layers and average concentrations across profiles (average $\pm 1 \sigma$, unit: $g \cdot \mathrm{kg}^{-1}$ ).

\begin{tabular}{|l|c|c|c|c|}
\hline Soil depth & Site 1 & Site 2 & Site 3 & Site 4 \\
\hline $0-10 \mathrm{~cm}$ & $45.47 \pm 0.17$ & $41.96 \pm 0.33$ & $28.6 \pm 0.58$ & $29.44 \pm 0.17$ \\
\hline $10-20 \mathrm{~cm}$ & $19.07 \pm 0.29$ & $19.51 \pm 0.77$ & $13.88 \pm 0.13$ & $16.99 \pm 0.06$ \\
\hline $20-30 \mathrm{~cm}$ & $18.96 \pm 0.33$ & $13.58 \pm 0.36$ & $9.65 \pm 0.17$ & $12.39 \pm 0.01$ \\
\hline $30-50 \mathrm{~cm}$ & $12.09 \pm 0.13$ & $12.76 \pm 0.51$ & $10.28 \pm 0.11$ & $11.35 \pm 0.32$ \\
\hline Average & 23.90 & 21.95 & 15.60 & 17.54 \\
\hline
\end{tabular}


Tab. 4: Distribution of values of SOC fractions in soil profiles (average $\pm 1 \sigma$, unit: $\mathrm{g} / \mathrm{kg}^{-1}$ ).

\begin{tabular}{|c|c|c|c|c|c|}
\hline & Soil depth & Site 1 & Site 2 & Site 3 & Site 4 \\
\hline \multirow{5}{*}{ LOC } & $0-10 \mathrm{~cm}$ & $5.41 \pm 0.35$ & $2.65 \pm 0.59$ & $3.7 \pm 0.12$ & $3.03 \pm 0.13$ \\
\hline & $10-20 \mathrm{~cm}$ & $1.65 \pm 0.04$ & $1.26 \pm 0.20$ & $0.96 \pm 0.04$ & $1.42 \pm 0.08$ \\
\hline & $20-30 \mathrm{~cm}$ & $1.66 \pm 0.04$ & $1.12 \pm 0.06$ & $1.00 \pm 0.08$ & $1.35 \pm 0.04$ \\
\hline & $30-50 \mathrm{~cm}$ & $0.82 \pm 0.02$ & $1.00 \pm 0.11$ & $0.97 \pm 0.04$ & $0.69 \pm 0.06$ \\
\hline & Average & 2.38 & 1.51 & 1.66 & 1.63 \\
\hline \multirow{5}{*}{ ROC } & $0-10 \mathrm{~cm}$ & $32.89 \pm 0.11$ & $35.05 \pm 0.55$ & $16.83 \pm 2.57$ & $15.25 \pm 0.99$ \\
\hline & $10-20 \mathrm{~cm}$ & $11.64 \pm 0.57$ & $12.45 \pm 0.27$ & $5.85 \pm 0.08$ & $9.68 \pm 0.55$ \\
\hline & $20-30 \mathrm{~cm}$ & $12.06 \pm 0.20$ & $8.71 \pm 0.13$ & $3.30 \pm 0.26$ & $7.17 \pm 0.20$ \\
\hline & $30-50 \mathrm{~cm}$ & $7.39 \pm 0.33$ & $7.00 \pm 0.26$ & $8.49 \pm 0.08$ & $4.49 \pm 0.13$ \\
\hline & Average & 15.99 & 15.80 & 8.62 & 9.15 \\
\hline \multirow{5}{*}{ Ca-SOC } & $0-10 \mathrm{~cm}$ & $2.27 \pm 0.10$ & $2.44 \pm 0.21$ & $1.18 \pm 1.02$ & $2.00 \pm 0.06$ \\
\hline & $10-20 \mathrm{~cm}$ & $1.39 \pm 0.03$ & $1.95 \pm 0.03$ & $1.03 \pm 0.02$ & $1.04 \pm 0.02$ \\
\hline & $20-30 \mathrm{~cm}$ & $1.18 \pm 0.02$ & $0.74 \pm 0.04$ & $0.96 \pm 0.07$ & $0.88 \pm 0.01$ \\
\hline & $30-50 \mathrm{~cm}$ & $0.95 \pm 0.08$ & $0.60 \pm 0.09$ & $0.82 \pm 0.08$ & $0.63 \pm 0.07$ \\
\hline & Average & 1.45 & 1.25 & 0.99 & 1.14 \\
\hline \multirow{5}{*}{$\mathrm{Fe}(\mathrm{Al})-\mathrm{SOC}$} & $0-10 \mathrm{~cm}$ & $20.41 \pm 1.30$ & $17.8 \pm 0.28$ & $8.77 \pm 2.70$ & $14.77 \pm 0.43$ \\
\hline & $10-20 \mathrm{~cm}$ & $11.31 \pm 0.85$ & $12.95 \pm 0.44$ & $9.84 \pm 2.64$ & $11.27 \pm 1.60$ \\
\hline & $20-30 \mathrm{~cm}$ & $13.6 \pm 0.61$ & $12.5 \pm 0.57$ & $9.34 \pm 0.31$ & $10.7 \pm 0.14$ \\
\hline & $30-50 \mathrm{~cm}$ & $11.62 \pm 0.58$ & $10.08 \pm 2.25$ & $9.43 \pm 1.29$ & $10.25 \pm 0.67$ \\
\hline & Average & 14.23 & 12.68 & 9.35 & 11.19 \\
\hline
\end{tabular}

Tab. 5: Proportions of SOC fractions in soil profiles.

\begin{tabular}{|c|c|c|c|c|c|}
\hline & Soil depth & Site 1 & Site 2 & Site 3 & Site 4 \\
\hline \multirow{5}{*}{ LOC/SOC } & $0-10 \mathrm{~cm}$ & 11.89 & 6.32 & 12.94 & 10.30 \\
\hline & $10-20 \mathrm{~cm}$ & 8.65 & 6.46 & 6.92 & 8.38 \\
\hline & $20-30 \mathrm{~cm}$ & 8.74 & 8.28 & 10.42 & 10.93 \\
\hline & $30-50 \mathrm{~cm}$ & 6.81 & 13.34 & 9.47 & 6.09 \\
\hline & Average & 9.02 & 8.60 & 9.94 & 8.93 \\
\hline \multirow{5}{*}{ ROC/SOC } & $0-10 \mathrm{~cm}$ & 72.34 & 83.54 & 58.84 & 51.81 \\
\hline & $10-20 \mathrm{~cm}$ & 61.03 & 63.81 & 42.18 & 56.97 \\
\hline & $20-30 \mathrm{~cm}$ & 63.59 & 64.16 & 34.21 & 57.88 \\
\hline & $30-50 \mathrm{~cm}$ & 61.12 & 51.52 & 82.63 & 39.54 \\
\hline & Average & 64.52 & 65.76 & 54.47 & 51.55 \\
\hline \multirow{5}{*}{$\mathrm{Ca}-\mathrm{SOC} / \mathrm{SOC}$} & $0-10 \mathrm{~cm}$ & 4.98 & 5.82 & 4.12 & 6.81 \\
\hline & $10-20 \mathrm{~cm}$ & 7.28 & 10.02 & 7.40 & 6.09 \\
\hline & $20-30 \mathrm{~cm}$ & 6.24 & 5.45 & 9.91 & 7.09 \\
\hline & $30-50 \mathrm{~cm}$ & 7.84 & 4.12 & 7.97 & 5.57 \\
\hline & Average & 6.59 & 6.35 & 7.35 & 6.39 \\
\hline \multirow{5}{*}{$\mathrm{Fe}(\mathrm{Al})-\mathrm{SOC} / \mathrm{SOC}$} & $0-10 \mathrm{~cm}$ & 44.89 & 42.41 & 30.66 & 50.17 \\
\hline & $10-20 \mathrm{~cm}$ & 59.32 & 66.38 & 70.94 & 66.34 \\
\hline & $20-30 \mathrm{~cm}$ & 71.72 & 92.03 & 96.86 & 86.35 \\
\hline & $30-50 \mathrm{~cm}$ & 96.05 & 74.22 & 91.77 & 90.31 \\
\hline & Average & 68.00 & 68.76 & 72.56 & 73.29 \\
\hline
\end{tabular}


Tab. 6: ROC/LOC ratios of sampled soil profiles.

\begin{tabular}{|l|c|c|c|c|}
\hline Soil depth & Site 1 & Site 2 & Site 3 & Site 4 \\
\hline $0-10 \mathrm{~cm}$ & 5.41 & 12.66 & 4.26 & 4.81 \\
\hline $10-20 \mathrm{~cm}$ & 7.31 & 11.21 & 6.41 & 6.56 \\
\hline $20-30 \mathrm{~cm}$ & 6.16 & 7.87 & 4.16 & 5.50 \\
\hline $30-50 \mathrm{~cm}$ & 18.55 & 9.59 & 5.20 & 6.49 \\
\hline Average & 9.36 & 10.33 & 5.01 & 5.84 \\
\hline
\end{tabular}

\section{CLAY WITH FINE AND MEDIUM-SIZED SILT, SOIL}

$$
\mathrm{CAO}, \mathrm{FE}_{2} \mathrm{O}_{3} \text { AND } \mathrm{AL}_{2} \mathrm{O}_{3} \text { CONTENT }
$$

Soil texture (contents of clay with fine and medium-sized silt), $\mathrm{CaO}, \mathrm{Fe}_{2} \mathrm{O}_{3}$, and $\mathrm{Al}_{2} \mathrm{O}_{3}$ in the soil profiles are illustrated in Fig. 3. According to the results of a paired-samples $t$-test, which shows whether there is a statistically significant difference between two paired observations, clay with fine and medium-sized silt content in soils developed on the carbonate bedrock was significantly higher than on the siliciclastic bedrock $(t=8.29, \mathrm{df}=7$, $p=0.000)$. $\mathrm{CaO}$ concentrations exhibited a trend similar to the trend exhibited by soil texture $(t=7.304, \mathrm{df}=7$, $p=0.000)$. However, there were no significant differences in $\mathrm{Fe}_{2} \mathrm{O}_{3}(\mathrm{t}=2.019, \mathrm{df}=7, p=0.083)$ and $\mathrm{Al}_{2} \mathrm{O}_{3}(\mathrm{t}=1.687$, $\mathrm{df}=7, p=0.135)$ contents display between carbonate bedrock and siliciclastic bedrock.

\section{SOC IN SOIL PROFILES}

Total SOC concentrations in the soil samples obtained from the areas with carbonate bedrock ranged between $12.1 \mathrm{~g} \cdot \mathrm{kg}^{-1}$ and $45.5 \mathrm{~g} \cdot \mathrm{kg}^{-1}$, with an average of $22.9 \mathrm{~g} \cdot \mathrm{kg}^{-1}$ across four depths (Fig. 4). In addition, SOC concentration decreased with an increase in depth in all the soil profiles.

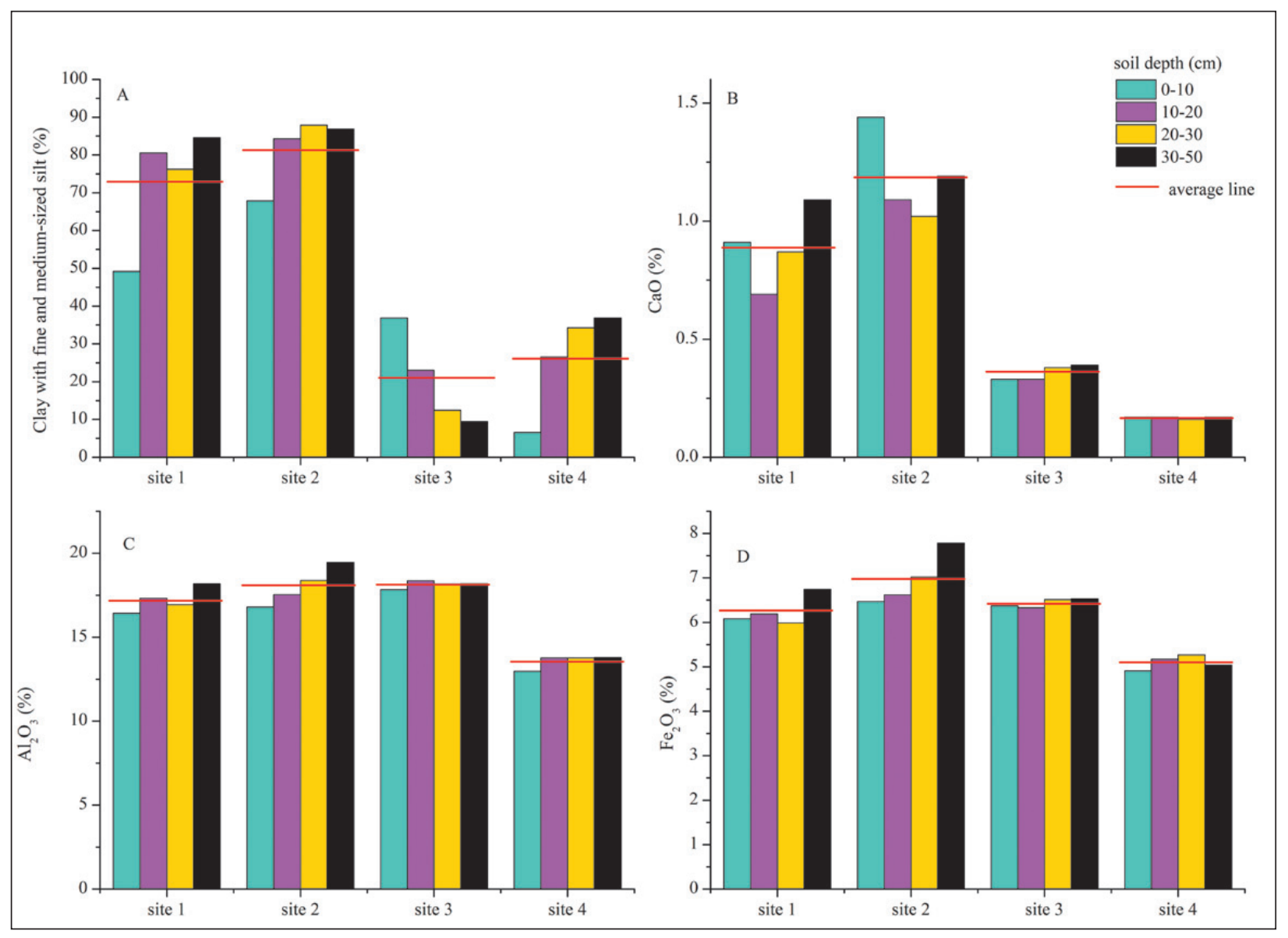

Fig. 3: Clay with fine and medium-sized silt (A), $\mathrm{CaO}(\mathrm{B}), \mathrm{Fe}_{2} \mathrm{O}_{3}(\mathrm{C})$, and $\mathrm{Al}_{2} \mathrm{O}_{3}(\mathrm{D})$ in soils developed in the soil profiles analysed. 


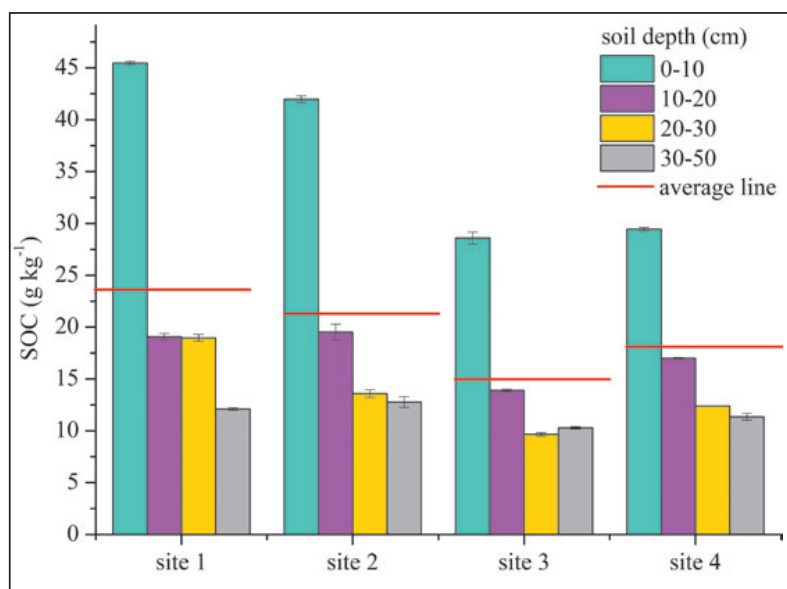

Fig. 4: Vertical distribution of SOC based on individual concentrations in sampled layers and average concentrations across profiles. The whiskers represent standard deviation $\pm 1 \sigma$.

In the sites with siliciclastic bedrock, SOC concentrations ranged between $9.7 \mathrm{~g} \cdot \mathrm{kg}^{-1}$ and $29.4 \mathrm{~g} \cdot \mathrm{kg}^{-1}$ across the four depths with an average of $16.4 \mathrm{~g} \cdot \mathrm{kg}^{-1}$. Similar to the SOC in carbonate soils, the SOC content in siliciclas- tic bedrock decreased exponentially with an increase in profile depth. Considering the entire soil profile or individual layers, the SOC concentrations in siliciclastic soils were $28 \%$ lower on average when compared with the SOC concentrations in carbonate soils (paired-samples $t$-test, $p=0.019)$. The greatest differences were observed in the uppermost $(0-10 \mathrm{~cm} ; 34 \%)$ and lowest layers $(30-50 \mathrm{~cm}$; $32 \%)$ sample. Conversely, the least differences were observed in the middle layers $(20-30 \mathrm{~cm} ; 20 \%)$. The least variability in SOC content was observed at similar depths between two forest types with similar lithological conditions (on average $11 \%$ in soils on carbonate bedrock and $18 \%$ on soils on siliciclastic bedrock). All these results suggest bedrock being the primary and type of forest the secondary factor influencing SOC concentration across soil profiles.

\section{SOC FRACTION DISTRIBUTIONS IN SOIL PROFILES AND RATIOS}

Similar to SOC content, $75 \%$ of SOC fractions exhibited decreases with an increase in profile depth (Fig. 5). The ROC concentrations were roughly 6.1 -fold the LOC con-

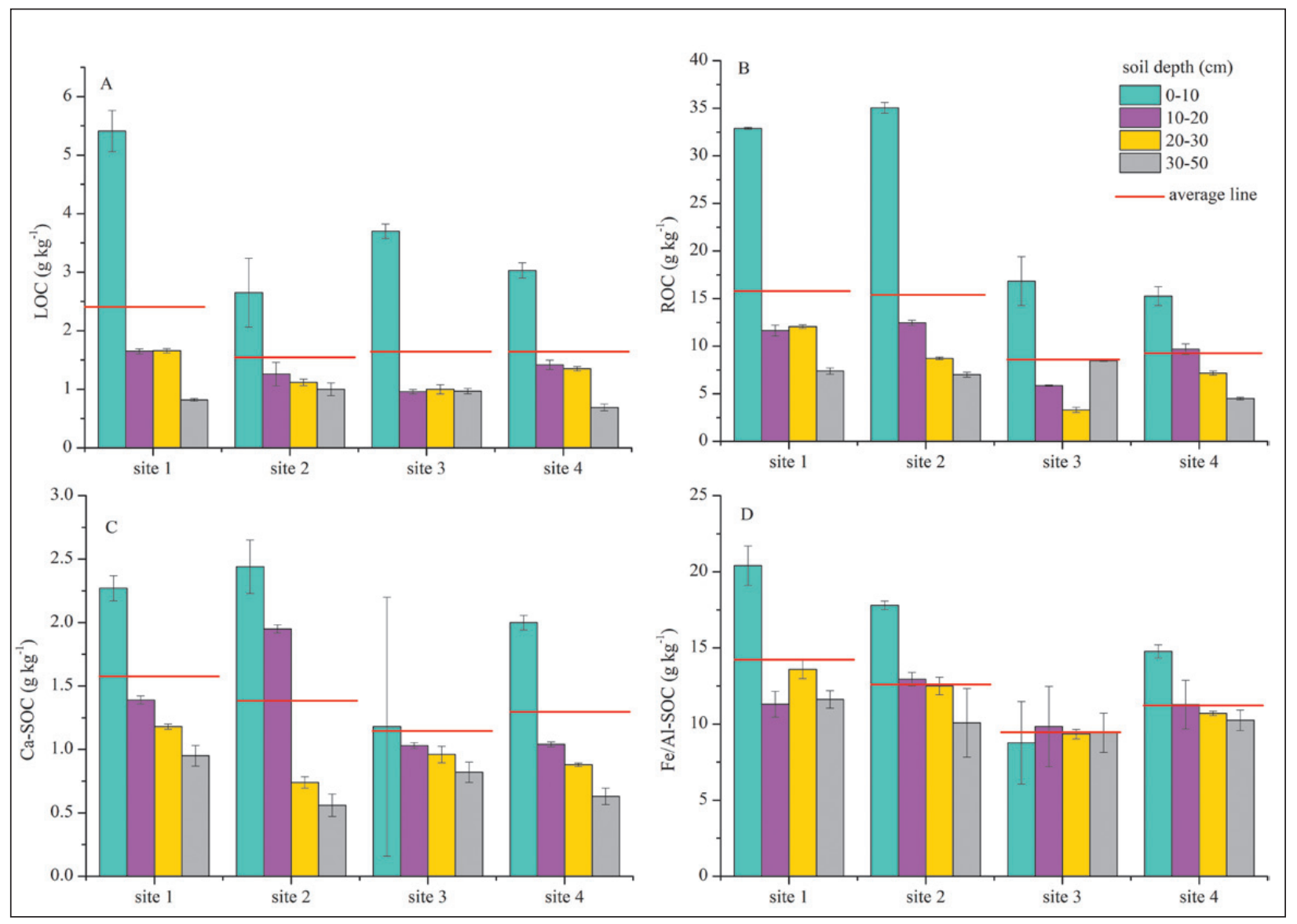

Fig. 5: Distribution of SOC fractions in soil profiles: (A) LOC, (B) ROC, (C) Ca-SOC, and (D) Fe/Al-SOC. The whiskers represent standard deviation $\pm 1 \sigma$. 


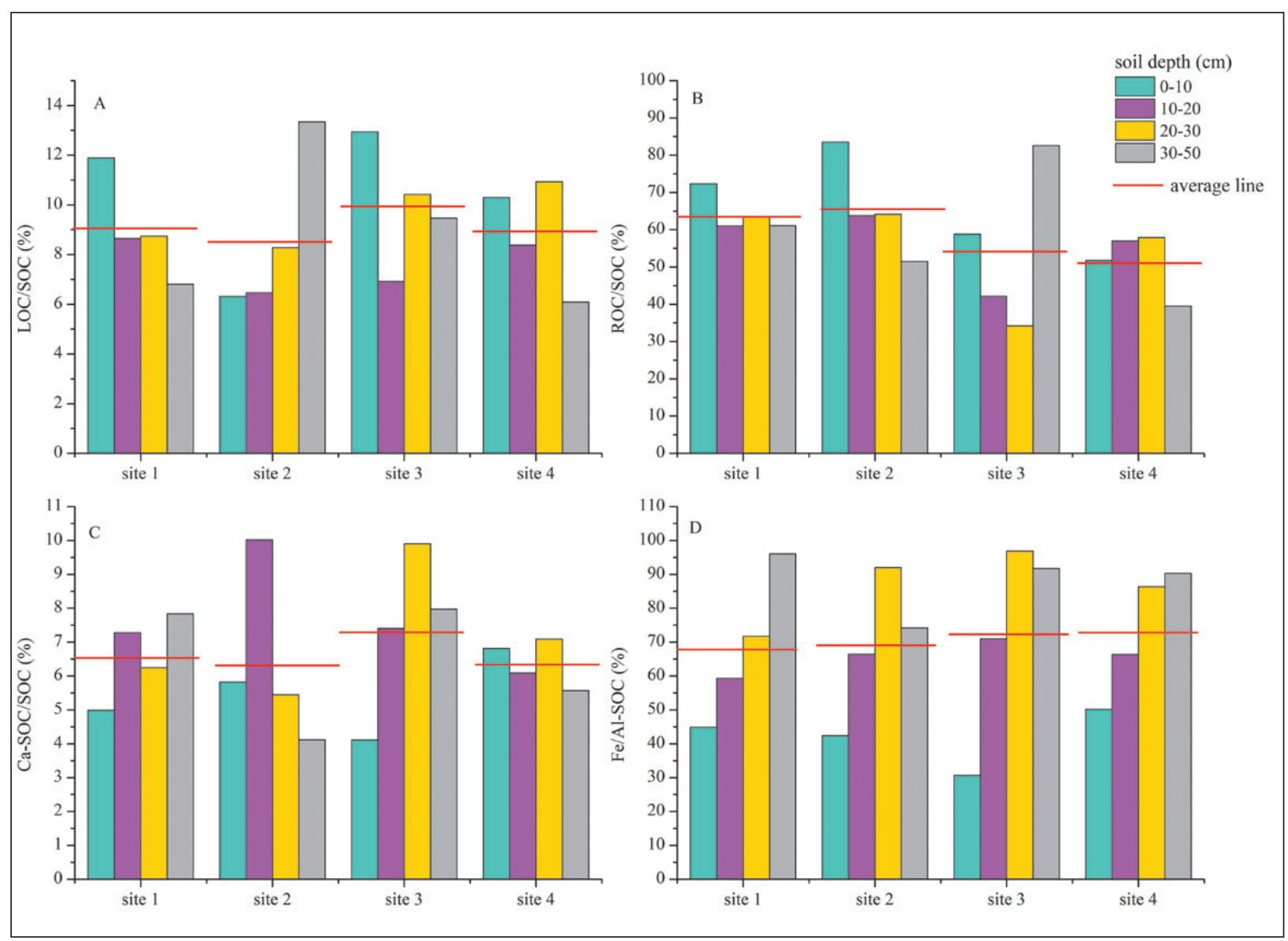

Fig. 6: Proportions of SOC fractions in soil profiles obtained from carbonate and siliciclastic bedrocks: (A) LOC/SOC, (B) ROC/SOC, (C) $\mathrm{Ca}-\mathrm{SOC} / \mathrm{SOC}$, and (D) Fe/Al-SOC/SOC.

centrations at similar soil depth at all sampling sites. In addition, even higher (10-fold) differences were observed for Fe/Al-SOC when compared with Ca-SOC concentrations at the same depth. Overall, ROC concentrations were significantly higher in soil developed on carbonate bedrock than in soil developed on siliciclastic bedrock $(p=0.032)$; however, LOC concentrations in soil developed in carbonate bedrock was not higher than LOC concentrations in soil developed on siliciclastic bedrock $(p=0.256)$.

Among the SOC fractions analysed, $\mathrm{ROC}$ and $\mathrm{Fe} /$ Al-SOC accounted for most of the SOC in the soil (51.5$65.8 \%$ and $68.0-73.3 \%$, respectively), while the Ca-SOC fraction accounted for a considerably lower proportion (6.4-7.4 \%; Fig. 6). There were no significant differences in LOC fraction concentrations between the soils developed on carbonate and siliciclastic bedrock $(p=0.256)$.
According to the results of the paired-samples $t$-test, there were no significant differences in LOC/SOC $(p=0.640)$, ROC/SOC $(p=0.077)$, Ca-SOC/SOC $(p=0.624)$, and $\mathrm{Fe} / \mathrm{Al}-\mathrm{SOC} / \mathrm{SOC}(p=0.354)$ ratios between soils developed on carbonate rocks and soils developed on siliciclastic bedrocks.

When the averages for all the profiles are taken into account, a high and significant correlation was observed between SOC and ROC $(p<0.05, \mathrm{r}=+0.97)$ and between $\mathrm{SOC}$ and Fe/Al-SOC $(p<0.05, r=+0.96)$. The correlation between SOC and LOC was much weaker $(r=+0.60)$. In addition, a high and significant correlation was observed between SOC and Ca-SOC $(r=+0.98)$, despite the low proportion of Ca-SOC within SOC (6.4-7.4\%), and the correlation between $\mathrm{Fe} / \mathrm{Al}-\mathrm{SOC}$ and $\mathrm{ROC}$ was high $(r=+0.90)$ and significant $(p=0.04)$. 


\section{DISCUSSION}

\section{SOC CONTENT AND SOC FRACTIONS DISTRIBUTION IN SOIL PROFILE}

In the present study, continuous exponential decreases in SOC and SOC fractions across all the analysed soil profiles indicated stabilized soil profiles without considerable anthropogenic influence. The absence of ploughing was evident since a decrease in SOC with an increase in depth was obvious, in addition to the lack of a sudden change in SOC concentration at the expected ploughed layer depth.

SOC content in soils represents a dynamic equilibrium between SOM inputs, such as litterfall deposits, crop residues, root exudates, and root biomass deposits, and SOM losses such as soil heterotrophic respiration (Benbi et al. 2015) and leaching. In the present study, the average SOC concentrations in the topsoil $(0-30 \mathrm{~cm})$ $\left(17.4-27.8 \mathrm{~g} \cdot \mathrm{kg}^{-1}\right)$ corresponded to the values expected in the region of Europe under study (Fraters et al. 1993) and was slightly more than the values reported in a previous study on Slovene soils by Fujiyoshi et al. (2011). With regards to soils developed on carbonate bedrocks, Šamonil (2007) reported SOC concentrations of $45.9 \mathrm{~g} \cdot \mathrm{kg}^{-1}$ (average value for $0-50-\mathrm{cm}$ depth) in Rendzic Leptosols and between $34.9 \mathrm{~g} \cdot \mathrm{kg}^{-1}(0-9-\mathrm{cm}$ depth) and $11.2 \mathrm{~g} \cdot \mathrm{kg}$ ${ }^{1}$ (9-52-cm depth) in Calcaric Cambisol under forest fragments including sections of the Bohemian Karst. Ahmed et al. (2012) measured SOC concentrations of $40 \mathrm{~g} \cdot \mathrm{kg}^{-1}$ in a karst soil in the Middle-European Forest Province in forest land and of $41 \mathrm{~g} \cdot \mathrm{kg}^{-1}$ in pasture land (average for 1-60-cm soil depth) and Ogrinc et al. (2016) reported SOC concentration of up to $39.1 \mathrm{~g} \cdot \mathrm{kg}^{-1}$ in the soil at depths of up to $35 \mathrm{~cm}$. In addition, all the studies above reported an exponential decrease in SOC concentration with an increase in depth, which was consistent with the findings of the present study. Comparison of the results of the present study with findings obtained from Maocun (South China), where similar ROC, LOC, Ca$\mathrm{SOC}$, and $\mathrm{Fe} / \mathrm{Al}-\mathrm{SOC}$ methods of determination were applied, revealed similar average SOC (18.7-19.3 g.kg $\left.{ }^{1}\right)$ and ROC (11.0-11.4 $\left.\mathrm{g} \cdot \mathrm{kg}^{-1}\right)$ concentrations, although the LOC concentrations were between 1.5- and 4-times lower (0.5-1.1 $\left.\mathrm{g} \cdot \mathrm{kg}^{-1}\right)$ than that in Maocun. In addition, the SOC concentrations and fractions declined with an increase in depth.

LOC and ROC are key intermediate phases of SOM decomposition from fresh organic material to inorganic end products, and they exhibit different trends with regards to the time scales of SOC turnover (formation and decomposition). While LOC has a rapid turnover rate with mean residence times (MRT) spanning up to sev- eral months, ROC has a relatively slower turnover rate with MRT ranging from dozens of years to hundreds of years (Davidson \& Janssens 2006; Zhou et al. 2013). This results in much higher ROC content compared to LOC content (ranging from 2.3- to 12.2-fold in the present study). The highest ROC and LOC concentrations were observed in the upper part of the soil profile, reflecting the primary sources of organic matter and the limited role of vertical migration. However, ROC is much less mobile in comparison with LOC. Therefore, the ROC/ LOC ratio is stable or increases slightly with an increase in depth (Fig. 7), which indicates the migration of LOC in the form of fulvic and humic acids into deeper soil profiles and the subsequent formation of ROC (while ROC in the upper part of the soil profile is mostly freshly decomposed OM). This was observed in the deciduous and mixed forest (sampling sites 1, 3, and 4). On the contrary, the spruce forest (sampling site 2) exhibited an opposite trend due to lower rates of fresh OM (needles) decomposition (Prescott et al. 2000), in addition to a less favourable environment for decomposition in the pure spruce forest (Prescott et al. 2000; Albers et al. 2004; Berger \& Berger 2012; Berger \& Berger 2014). Regarding the LOC/ SOC and ROC/SOC ratios, no pattern was observed with an increase in depth (Fig. 6), suggesting unique dynamics at each sampling site. The ROC/SOC ratio on the carbonate bedrock was on average slightly and significantly higher $(p=0.025)$ than the ROC/SOC ratio in the siliciclastic rock. The LOC/SOC ratio remained relatively constant with an increase in soil depth, which suggests LOC leaching and root production. A high Fe/Al-SOC ratio (Fig. $6 \mathrm{D}$ ) indicated that a considerable share of $\mathrm{OM}$ was bonded to $\mathrm{Fe} / \mathrm{Al}$ minerals, which is consistent with

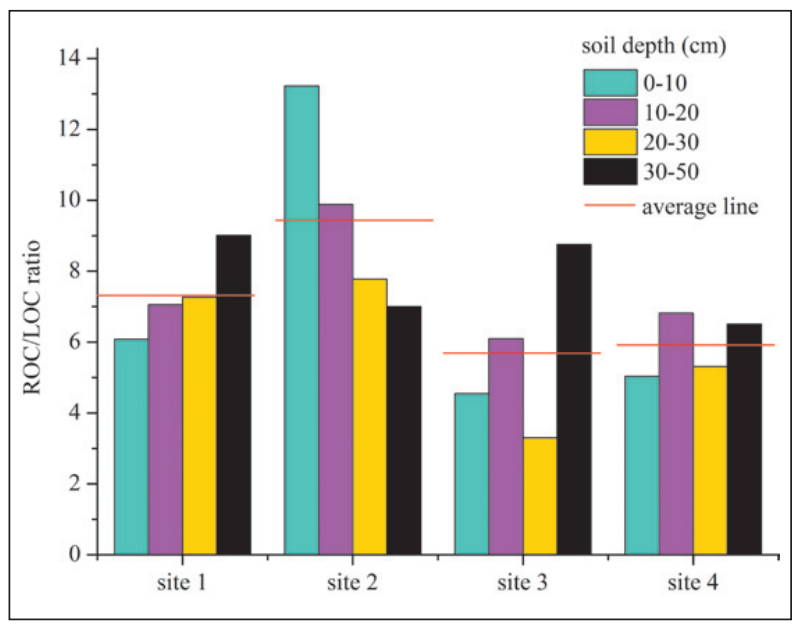

Fig. 7: ROC/LOC ratios of sampled soil profiles. 
the findings of Xu et al.(1999), which further enhances SOM stabilization (Wagai \& Mayer 2007; Adhikari \& Yang 2015; Zhao et al. 2016).

The high correlation observed in the present study between SOC and ROC, and between SOC and Fe/AlSOC was expected due to the high proportions of ROC (51.5-65.8\% on average) and Fe/Al-SOC (68.0-73.3\% on average) within SOC. The weaker correlation between LOC and SOC was due to the lower LOC concentrations compared to the SOC concentrations at site 2 at $0-10$ $\mathrm{cm}$ depth (Fig. 6A). The high and significant correlation observed between SOC and Ca-SOC $(r=+0.98)$ despite the low fraction of Ca-SOC within SOC (6.4-7.4 \%) suggests the fixation of SOC into Ca-SOC complexes, while the high and significant correlation between $\mathrm{Fe} / \mathrm{Al}-\mathrm{SOC}$ and ROC ( $p=0.04, r=+0.90)$ was potentially due to the stabilization of SOC (ROC formation) with Fe/Al-bound humus complex.

\section{RELATIONSHIP OF SOC AND ITS FRACTIONS WITH SOIL CHARACTERISTICS}

According to Greenland (1965), between 51 and $98 \%$ of all SOM is bound in complexes with clay minerals, which indicates that clay content influences SOC concentration. Furthermore, Eusterhues et al. (2005) reported a relationship between the OM resistance to oxidative degradation and the clay concentration in soil, which highlighted the role of clay minerals in the stabilization and accumulation of SOC. In addition, relatively higher clay contents could enhance soil aggregate stability, in turn leading to higher SOC stock (Eze et al. 2018).

Despite determination of clay content together with fine and medium-sized silt, the average clay with fine and medium-sized silt contents in soils were positively correlated with SOC $(r=+0.94)$. This was evident when clay content was compared with SOC concentration within individual soil layers. However, SOC content primarily depends on SOC source (litter) and decreases with an in- crease in depth due to weak downward migration, while clay content across layers depends on leaching, exhibiting the lowest concentrations at the surface. Although a negative correlation can be expected, it is potentially coincidentally important $(r \leq-0.99)$. This was demonstrated by the results at sampling site 3 , where the correlation between SOC and clay with fine and medium-sized silt content was highly positive $(r=+0.96)$ due to a decrease in clay with fine and medium-sized silt content with an increase in depth. Insights based on the correlation between clay with fine and medium-sized silt content and SOC reveal that the high correlation $(r=+0.94)$ is largely due to the vast difference between soils on karst bedrock, in which SOC and clay with fine and medium-sized silt contents are very high, and soils on siliciclastic bedrock, where SOC and clay with fine and medium-sized silt concentrations are low.

Associations can occur through the adsorption of organic matter onto minerals, including oxides, and through the co-precipitation of organic ligands with $\mathrm{Fe}$ and $\mathrm{Al}$ (Kleber et al. 2015). Such associations play key roles in the stabilisation of organic carbon in soils (e.g., Eusterhues et al. 2003, 2005; Schrumpf et al. 2013). Previous studies have showed that SOC interacts with inorganic minerals to give rise to organic-mineral complexes that can provide SOM protection against degradation and mineralization physically (Crow et al. 2007, Mikutta et al. 2009). Such associations are facilitated by microbial activities on mineral surfaces (e.g., KögelKnabner et al. 2008). The results of the present study show that the primary factor for associations influencing the average SOC concentration in the soil profile is the $\mathrm{CaO}$ content $(r=+0.82)$, although the influence is not significant ( $\mathrm{p}=0.11$; Tab. 7). The correlation between average $\mathrm{SOC}$ and average soil $\mathrm{Fe}_{2} \mathrm{O}_{3}$ and $\mathrm{Al}_{2} \mathrm{O}_{3}$ was much weaker, $r=+0.36$ and $r=+0.24$, respectively, and not any higher when comparing data based on soil layers $(+0.60 \leq r[S O C / C a O] \leq+0.84,-0.14 \leq r[S O C /$

Tab. 7: Pearson's correlation coefficients between SOC (with SOC fractions) and basic soil properties. Significant correlations ( $p \leq 0.05)$ are bolded.

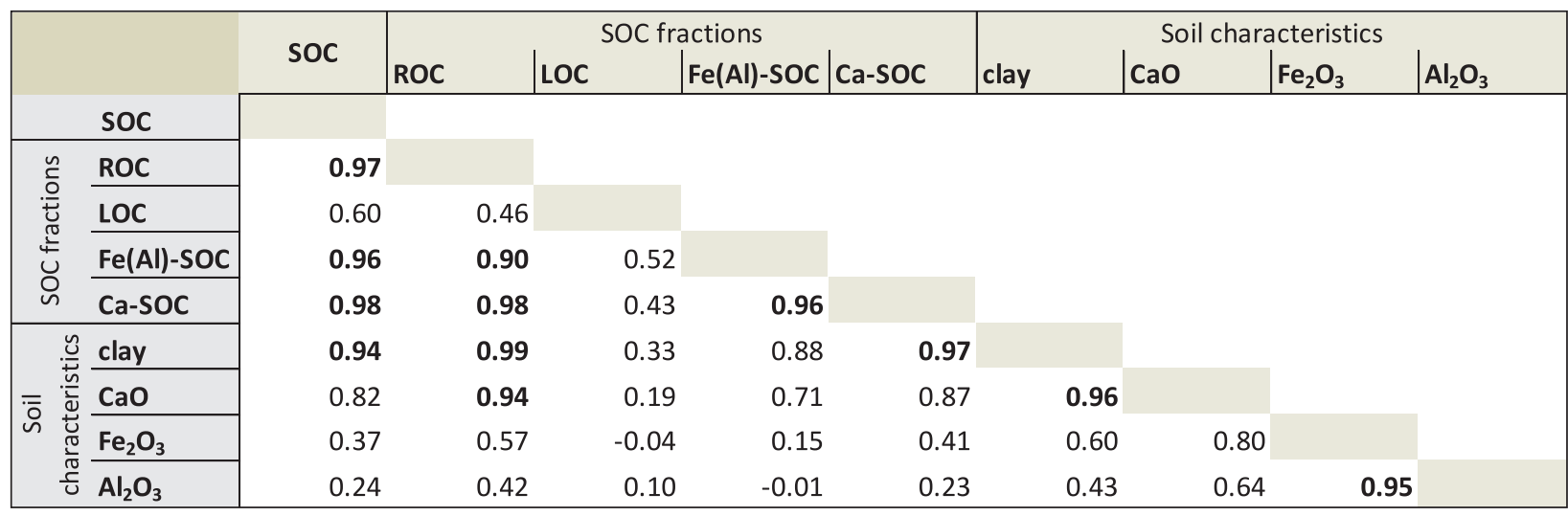


$\left.\left.\mathrm{Fe}_{2} \mathrm{O}_{3}\right] \leq+0.53,-0.12 \leq r\left[\mathrm{SOC} / \mathrm{Al}_{2} \mathrm{O}_{3}\right] \leq+0.33\right)$. The results highlight the important role of the specific iron and alumina oxides in complexation bonding rather than the total amount of iron and alumina oxides. Indeed, Kaiser and Guggenberger (2000) reported that reactive iron phases, such as $\mathrm{Al}$ and $\mathrm{Fe}$ oxyhydroxides, which are observed at poor concentrations in sediments from karst surfaces in the study area when compared to clay minerals (Zupan Hajna 1992), play a key role in the sorption of dissolved organic carbon. Analysis of the $\mathrm{CaO}$, $\mathrm{Fe}_{2} \mathrm{O}_{3}$, and $\mathrm{Al}_{2} \mathrm{O}_{3}$ concentrations in the soil profiles in the present study, in addition to the average ROC and LOC concentrations, revealed greater correlation with ROC $(+0.42 \leq r \leq+0.94)$ and weak correlation with LOC $(-0.04 \leq r \leq+0.19)$. This indicated potentially higher associations between reactive iron oxides and ROC compared to with LOC. The results are consistent with the findings of Kaiser and Gugenberger (2003); however, further investigations on clay minerals in soils are required to validate the finding.

Since ROC and Fe/Al-SOC constituted the major SOC components, similar relationships with soil properties were observed for $\mathrm{Ca}-\mathrm{SOC}$ with somewhat lower Pearson correlation coefficients for Fe/Al-SOC (Tab. 7). Correlations between LOC and other SOC fractions or soil properties were generally very weak $(-0.04 \leq r \leq+0.52)$ because of high LOC activity.

\section{EFFECTS OF BEDROCK LITHOLOGY ON SOC AND SOC FRACTIONS}

According to Ogrinc et al. (2016), bedrock geology is one of the key factors influencing soil carbon dynamics and isotopic carbon composition. In the present study, soil developed on carbonate bedrock contained on average $7.9 \mathrm{~g} \cdot \mathrm{kg}^{-1}$ more SOC than soil developed on siliciclastic bedrock under the similar climate conditions. These results are similar to the results of a comparative study between a karst region and a clasolite region under similar climate conditions in Maocun, South China (Cao et al. 2011; Yang et al. 2012). In the present study, according to paired-samples $t$-test, SOC concentrations in carbonate bedrock also exhibited significantly higher values when compared to siliciclastic bedrock ( $p=0.019)$.

Soils developed on carbonate rock had substantially higher clay and $\mathrm{CaO}$ concentrations than soils developed on siliciclastic bedrock (Fig. 3). Consequently, higher concentrations of stabilized OM, including ROC and stabilised SOC fractions such as $\mathrm{Ca}-\mathrm{SOC}$ and $\mathrm{Fe} / \mathrm{Al}-\mathrm{SOC}$, in soils developed on carbonate rocks, was not surprising since in numerous cases, organo-mineral associations result in the formation of heterogeneous microaggregates, including silicates, oxides, and organic entities (e.g., Lehmann et al. 2007). Calcium ions bridging with macromolecular humic acid leads to the formation of larger colloids, while smaller colloids are formed under calcium ions bridging with lower molecular humic matter (Lin et al. 2015). Consequently, calcium-bound humic acid is not easily decomposed (Cao et al. 2003) and increases ROC concentrations, as observed in the present study. Similarly, all other SOC fractions, excluding LOC, were higher in carbonate soils due to bonding with clay minerals. Nevertheless, this requires further studies, since $\mathrm{Fe}_{2} \mathrm{O}_{3}$ mineral/chemical composition influences $\mathrm{OM}$ complexation. Since LOC is mobile and not attached to clay or calcium in the form of organo-mineral complexes, LOC concentrations are quite similar between carbonate and siliciclastic soils. This explains why soils developed on carbonate bedrock have higher SOC concentrations than soils developed on siliciclastic bedrock.

The proportions of all the SOC fractions analysed in the present study exhibited no significant difference for all SOC fractions between the two environments investigated. However, there were slightly higher ROC/SOC ratios in soils on carbonate bedrock (Fig. 6B, which was also reported in the Maocun area, South China (Cao et al. 2011).

\section{CONCLUSIONS}

In the present study, we quantified and evaluated SOC and its fractions in four forest soil profiles (two developed on carbonate and two on siliciclastic bedrock) in the centre of the Classical Karst, NW part of the Dinaric Karst. In all the soil profiles analysed, SOC concentrations in addition to and most of the $\mathrm{SOC}$ fraction concentrations (LOC, ROC, and Ca-SOC) decreased with an increase in depth, which indicated a stabilized soil profile, with litter as the major SOM input. The SOC concentrations in the present study were generally consistent with previous studies on European karst soils in temperate climate zones. ROC and Fe/Al-SOC were the most abundant SOC fractions, while Ca-SOC and LOC fractions were lower. $\mathrm{ROC}$ and $\mathrm{Fe} / \mathrm{Al}-\mathrm{SOC}$ contents accounted for more than $50 \%$ of the SOC, while LOC and Ca-SOC accounted for less than $10 \%$ of the SOC contents. ROC/LOC ratio increased with an increase in soil depth due to a decrease in litter input, transformation of LOC into ROC, and 
microbiological activity, which enhances decomposition rate of LOC compared to ROC. Such trends may be observed in soils under deciduous and mixed forests, while soils under spruce forests would exhibit opposite trends due to relatively high ROC concentrations and low LOC concentrations close to the surface, which indicate conditions unfavourable for the decomposition of OM. The average SOC contents in the profiles were highly correlated with stable and mineral-complexed SOC fractions (ROC, Fe/Al-SOC and $\mathrm{Ca}-\mathrm{SOC}$ ), while the correlation between SOC and mobile LOC was much lower and statistically insignificant.

High proportions of ROC and Fe/Al-SOC fractions in the total SOC, in addition to the high correlation between $\mathrm{Ca}-\mathrm{SOC}$ and SOC, indicated the key roles of $\mathrm{Ca}-$ related and some clay Fe/Al-related minerals in the formation of mineral-complexes stabilizing and increasing SOC content, which is consistent with the generally accepted theory. Conversely, the weak correlation between SOC and its fractions with $\mathrm{Fe}_{2} \mathrm{O}_{3}$ and $\mathrm{Al}_{2} \mathrm{O}_{3}$ were not as anticipated; most probably due to the high proportion of non-reactive forms of $\mathrm{Fe}$ - and $\mathrm{Al}$-related minerals, such as clay minerals, which are the most abundant $\mathrm{Fe}$ - and Al-related minerals, at least in karst soils.

Due to the high clay and calcium contents SOC concentration developed in carbonate bedrock were significantly higher than the SOC concentrations in siliciclastic bedrock soils. Although the differences in LOC concentrations could not be explained based on the potential influences of bedrock lithology, higher SOC concentrations were associated with the higher ROC and Fe/Al-SOC concentrations observed in the carbonate bedrock soils.

Although the present study focuses on SOC and specifically its fractions in few soil profiles and not on the high number of soil profiles, more studies should investigate the potential influence of bedrock lithology on SOC and its fractions under different climate types. Such studies could provide some insights into the SOM and the soil carbon cycle dynamics, particularly in OM-enriched karst soils in light of anticipated climate changes. In addition, the role of the mineral/chemical compositions of Fe- and Al-related oxyhydroxides in the stabilization of OM compared to overall $\mathrm{Fe}_{2} \mathrm{O}_{3}$ and $\mathrm{Al}_{2} \mathrm{O}_{3}$ concentrations remains poorly understood.

\section{ACKNOWLEDGEMENT}

This study was supported by Inter-governmental Scientific and Technological Cooperation Projects Grant No.10-18, the Natural Scientific Foundation of Guangxi in China Grant No.2017GXNSFAA198153, the China Scholarship Council Fund Grant No.201608450017, the
Guangxi Science Research and Technology Development Project Grant No. Guikeneng 1598023-1, the SinoSlovene bilateral research projects BI-CN/14-15-018 and BI-CN/17-18-014, and the P6-0119 Karst Research Programme founded by the Slovenian Research Agency.

\section{REFERENCES}

Adhikari, D. \& Y. Yang, 2015: Selective stabilization of aliphatic organic carbon by iron oxide.- Scientific Reports, 5, 11214.

Ahmed, Y. A.-R., Pichler, V., Homolák, M., Gömöryová, E., Nagy, D., Pichlerová M. \& J. Gregor, 2012: High organic carbon stock in a karstic soil of the MiddleEuropean Forest Province persists after centurieslong agroforestry management.- European Journal of Forest Research, 131, 1669-1680.

Albers, D., Migge, S., Schaefer, M. \& S. Scheu, 2004: Decomposition of beech leaves (Fagus sylvatica) and spruce needles (Picea abies) in pure and mixed stands of beech and spruce.- Soil Biology and Biochemistry, 36, 1, 155-164.
Banger, K., Kukal, S. S., Toor, G., Sudhir K. \& T. H. Hanumanthraju, 2009: Impact of long-term additions of chemical fertilizers and farm yard manure on carbon and nitrogen sequestration under rice-cowpea cropping system in semi-arid tropics.- Plant and Soil, 318, 27-35.

Bao, S. D., 2000: Soil agricultural chemistry analysis.China Agriculture Press, 30-34, Beijing.

Barré, P., Durand, H., Chenu, C., Meunier, P., Montagne, D., Castel, G., Billiou, D., Soucémarianadin L. \& L. Cécillon, 2017: Geological control of soil organic carbon and nitrogen stocks at the landscape scale.Geoderma, 285, 50-56.

Belay-Tedla, A., Zhou, X., Su, B., Wan S. \& Y. Luo, 2009: 
Labile, recalcitrant, and microbial carbon and nitrogen pools of a tallgrass prairie soil in the US Great Plains subjected to experimental warming and clipping.- Soil Biology and Biochemistry, 41, 110-116.

Benbi, D. K., Brar, K., Toor A. S. \& P. Singh, 2015: Total and labile pools of soil organic carbon in cultivated and undisturbed soils in northern India.- Geoderma, 237-238, 149-158.

Berger, T. \& P. Berger, 2012: Greater accumulation of litter in spruce (Picea abies) compared to beech (Fagus sylvatica) stands is not a consequence of the inherent recalcitrance of needles.- An International Journal on Plant-Soil Relationships, 358, 1, 349-369.

Berger, T. \& P. Berger, 2014: Does mixing of beech (Fagus sylvatica) and spruce (Picea abies) litter hasten decomposition?- An International Journal on PlantSoil Relationships, 3771, 217-234.

Blair, G., Lefroy R. \& L. Lisle, 1995: Soil carbon fractions based on their degree of oxidation, and the development of a carbon management index for agricultural systems.- Australian Journal of Agricultural Research, 46, 1459-1466.

Buser, S., Grad, K. \& M. Pleničar, 1967: Osnovna geološka karta SFRJ, list Postojna 1:100000.- Zvezni geološki zavod, Beograd.

Cai, A., Feng, W., Zhang W. \& M. Xu, 2016: Climate, soil texture, and soil types affect the contributions of fine-fraction-stabilized carbon to total soil organic carbon in different land uses across China.- Journal of Environmental Management, 172, 2-9.

Cao, J., Yuan, D. \& G. Pan, 2003: Some soil features in karst ecosystem.- Advance in Earth Sciences, 18, 3744. (in Chinese with English abstract)

Cao, J., Zhou, L., Yang, H., Lu Q. \& Z. Kang, 2011: Comparison of carbon transfer between forest soils in karst and clasolite areas and the karst carbon sink effect in Maocun village of Guilin.- Quaternary Sciences, 31, 431-437. (in Chinese with English abstract)

Chen, Z., Auler, A.S., Bakalowicz, M., Drew, D., Griger, F., Hartmann, J., Jiang, G., Moosdorf, N., Richts, A., Stevanovic, Z., Veni, G. \& N. Goldscheider, 2017: The World Karst Aquifer Mapping project: concept, mapping procedure and map of Europe.- Hydrogeology Journal, 25, 771-785. doi:10.1007/s10040016-1519-3.

Crow, S. E., Swanston, C. W., Lajtha, K., Brooks, J. R. \& H. Keirstead, 2007: Density fractionation of forest soils: methodological questions and interpretation of incubation results and turnover time in an ecosystem context.- Biogeochemistry, 85, 69-90.

Davidson, E. A. \& I. A. Janssens, 2006: Temperature sen- sitivity of soil carbon decomposition and feedbacks to climate change.- Nature, 440, 165-173.

Eusterhues, K., Rumpel, C. \& I. Kögel-Knabner, 2005: Organo-mineral associations in sandy acid forest soils:importance of specific surface area, iron oxides and micropores.- European Journal of Soil Science, $56,753-763$.

Eusterhues, K., Rumpel, C., Kleber, M. \& I. Kögel-Knabner, 2003: Stabilisation of soil organic matter by interactions with minerals as revealed by mineral dissolution and oxidative degradation.- Organic Geochemistry, 34, 12, 1591-1600.

Eze, S, Palmer, S. M. \& P J. Chapman, 2018: Soil organic carbon stock and fractional distribution in upland grasslands.- Geoderma, 314,175-183.

Ford, D. \& P. Williams, 2007: Karst Hydrogeology and Geomorphology.- John Wiley \& Sons, Ltd., pp. 562, West Sussex, England.

Fraters, D., Bouwman, A.F. \& T.J.M. Thewessen, 1993: Soil Organic Matter Map if Europe. Estimates of soil organic matter content of the topsoil of FAO-Unesco soil units. Bilthoven, National Institute of Public Health and Environmental Protection, $60 \mathrm{pp}$.

Fujiyoshi, R., Amano, H., Sakuta, Y., Okamoto, K., Sumiyoshi, T., Kobal, I. \& J. Vavpotič, 2011: Practical evaluation of carbon sources of forest soils in Slovenia from stable and radio-carbon isotope measurements.- Environmental Earth Sciences, 67, 1.

Gombert, P., 2002: Role of karstic dissolution in global carbon cycle.- Global and Planetary Change, 33, 1, 177-184.

Grčman, H., Vidic, N. J., Zupan, M., Lobnik, F., Jones, A. \& L. Montanarella, 2015: Soils of Slovenia with soil map 1:250.000.- European Commission JRC Institute for Environment and Sustainability, pp. 187, Luxemburg.

Greenland, D. J., 1965: Interactions between clays and organic compounds in soils. I. Mechanisms of interaction between clays and defined organic compounds.- Soils Fert., 28, 415-425.

Houghton, R. A., Davidson, E. A. \& G. M. Woodwell, 1998: Missing sinks, feedbacks, and understanding the role of terrestrial ecosystems in the global carbon balance.- Global Biogeochemical Cycles, 12, 1, 25-34.

Jones, R. J. A., Hiederer, R., Rusco E. \& L. Montanarella, 2005: Estimating organic carbon in the soils of Europe for policy support.- European Journal of Soil Science, 56, 655-671.

Kaiser, K. \& G. Guggenberger, 2000: The role of DOM sorption to mineral surfaces in the preservation of organic matter in soils.- Organic Geochemistry, 31, 7-8, 711-725. 
Kaiser, K. \& G. Guggenberger, 2003: Mineral surfaces and soil organic matter.- European Journal of Soil Science, 54, 219-236.

Kaligarič, M., Culiberg, M. \& B. Kramberger, 2006: Recent vegetation history of the North Adriatic grasslands: expansion and decay of an anthropogenic habitat.- Folia geobotanica, 41, 3, 241-258.

Kleber, M., Eusterhues, K., Keiluweit, M. , Mikutta, C., Mikutta, R. \& P. S. Nico, 2015: Mineral-organic associations: Formation, properties, and relevance in soil environments.- Advances in Agronomy, 130, 2,1-140.

Kögel-Knabner, I., Guggenberger, G., Kleber, M., Kandeler, E., Kalbitz, K., Scheu, S., Eusterhues, K. P. Leinweber, 2008: Organo-mineral associations in temperate soils: Integrating biology, mineralogy, and organic matter chemistry.- Journal of Plant Nutrition and Soil Science, 171, 61-82.

Lal, R., 2004: Soil carbon sequestration to mitigate climate change.- Geoderma, 123, 1, 1-22.

Lehmann, J., Kinyangi, J. \& D. Solomon, 2007: Organic matter stabilisation in soil microaggregates: Implications from spatial heterogeneity of organic carbon contents and carbon forms.- Biogeochemistry, 85, 45-57.

Lin, T., Lu, Z. \& W. Chen, 2015: Interaction mechanisms of humic acid combined with calcium ions on membrane fouling at different conditions in an ultrafiltration system.- Desalination, 357,26-35.

Liu, M., Chang, Q., Qi, Y., Liu, J. \& T. Chen, 2014: Aggregation and soil organic carbon fractions under different land uses on the tableland of the Loess Plateau of China.- Catena, 115, 3,19-28.

Liu, X., Li, L., Qi, Z., Han J. \& Y. Zhu, 2017: Land-use impacts on profile distribution of labile and recalcitrant carbon in the Ili River Valley, northwest China.- Science of The Total Environment, 586, 10381045.

Liu, Z., Dreybrodt, W. \& H. Wang, 2010: A new direction in effective accounting for the atmospheric $\mathrm{CO}_{2}$ budget: considering the combined action of carbonate dissolution, the global water cycle and photosynthetic uptake of DIC by aquatic organisms.- EarthScience Reviews, 99, 3, 162-172.

Loginow, W., Wisniewski, W., Gonet, S. S. \& B. Ciescinska, 1987: Fractionation of organic carbon based on susceptibility to oxidation.- Polish Journal of Soil Science, 20, 47-52.

Mikutta, R., Schaumann, G. E., Gildemeister, D., Bonneville, S., Kramer, M. G., Chorover, J., Chadwick, O. A. \& G. Guggenberger, 2009: Biogeochemistry of mineral-organic associations across a long-term mineralogical soil gradient (0.3-4100kyr), Hawai- ian Islands.- Geochimica et Cosmochimica Acta, 73, 2034-2060.

Ogrinc, N., Kanduč, T., Krajnc, B., Vilhar, U., Simončič, P. \& L. Jin, 2016: Inorganic and organic carbon dynamics in forested soils developed on contrasting geology in Slovenia-a stable isotope approach.Journal of Soils and Sediments, 16, 382-395.

Parton, W. J., Schimel, D. S., Cole, C. V. \& D. S. Ojima, 1987: Analysis of factors controlling soil organic matter levels in Great Plains Grasslands.- Soil Science Society of America Journal, 51, 1173-1179.

Pavlovec, R., 1981: Fliš v Postojni (Flysch from Postojna). - Geologija, 24, 2, 285-301.

Peel, M. C., Finlayson, B. L. \& T. A. McMahon, 2007: Updated world map of the Köppen-Geiger climate classification.- Hydrol. Earth Syst. Sci., 11, 1633-1644.

Prescott, C. E., Zabek, L. M., Staley, C. L. \& R. Kabzems, 2000: Decomposition of broadleaf and needle litter inforests of British Columbia: influences of littertype, forest type, and litter mixtures.- Canadian Journal of Forest Research, 30, 1742-1750.

Purakayastha, T. J., Chhonkar, P. K., Bhadraray, S., Patra, A. K., Verma, V. \& M. A. Khan, 2007: Long-term effects of different land use and soil management on various organic carbon fractions in an Inceptisol of subtropical India.- Soil Research, 45, 33-40.

Rovira, P. \& V. R. Vallejo, 2002: Labile and recalcitrant pools of carbon and nitrogen in organic matter decomposing at different depths in soil: an acid hydrolysis approach.- Geoderma, 107, 109-141.

Rovira, P. \& V. R. Vallejo, 2007: Labile, recalcitrant, and inert organic matter in Mediterranean forest soils.Soil Biology and Biochemistry, 39, 202-215.

Šamonil, P., 2007: Uniqueness of limestone soil-forming substrate in the forest ecosystem classification.Journal of Forest Science, 53, 149-161.

Schmidt, M. W. I., Torn, M. S., Abiven, S., Dittmar, T., Guggenberger, G., Janssens, I. A., Kleber, M., KogelKnabner, I., Lehmann, J., Manning, D. A. C., Nannipieri, P., Rasse, D. P., Weiner, S. \& S. E. Trumbore, 2011: Persistence of soil organic matter as an ecosystem property.- Nature, 478, 49-56.

Schrumpf, M., Kaiser, K., Guggenberger, G., Persson, T., Kögel-Knabner, I. \& E.-D. Schulze, 2013: Storage and stability of organic carbon in soils as related to depth, occlusion within aggregates, and attachment to minerals.- Biogeosciences, 10, 1675-1691.

Šebela, S. \& J. Čar, 2000: Velika Jeršanova Dolina-A Former Collapse Doline.- Acta Carsologica, 29, 2, 201212.

Šebela, S., Zupančič, N., Miler, M., Grčman, H. \& S. Jarc, 2017: Evidence of Holocene surface and nearsurface palaeofires in karst caves and soils.- Palaeo- 
geography, Palaeoclimatology, Palaeoecology, 485, 224-235.

Wagai, R. \& L. M. Mayer, 2007: Sorptive stabilization of organic matter in soils by hydrous iron oxides.Geochimica et Cosmochimica Acta, 71, 25-35.

Wang, C., Li, F., Shi, H., Jin, Z., Sun, X., Zhang, F., Wu, F. \& S. Kan, 2013: The significant role of inorganic matters in preservation and stability of soil organic carbon in the Baoji and Luochuan loess/paleosol profiles, Central China.- Catena, 109, 186-194.

Wang, Y. \& Y.-P. Hsieh, 2002: Uncertainties and novel prospects in the study of the soil carbon dynamics.Chemosphere, 49, 791-804.

Wang, Z., Liu, S., Huang, C., Liu, Y. \& Z. Bu, 2017: Impact of land-use change on profile distributions of organic carbon fractions in peat and mineral soils in Northeast China.- Catena, 152, 1-8.

Xiao, W., Feng, S., Liu, Z. , Su, Y., Zhang, Y. \& X. He, 2017: Interactions of soil particulate organic matter chemistry and microbial community composition mediating carbon mineralization in karst soils.- Soil Biology and Biochemistry, 107, 85-93.

Xu, J., Sai, F. \& K. Yuan, 1999: Studies on organo-mineral complexes in soil IX. characteristics of humus in calcium-bound and iron/aluminum-bound organomineral complexes in soil.- Acta Pedologica Sinica, 36, 168-178. (in Chinese with English abstract)
Xu, X., Zhang, W., Xu, M., Li, S., An, T., Pei, J., Xiao, J., Xie, H. \& J. Wang, 2016: Characteristics of differently stabilised soil organic carbon fractions in relation to long-term fertilisation in Brown Earth of Northeast China.- Science of The Total Environment, 572, 1101-1110.

Yang, H., Zhang, L., Yu, S. \& J. Cao, 2012: Effects of different land-uses on the features of water-stable aggregates in karst and clasolite areas in Maocun, Guilin.- Carsologica Sinica, 31, 265-271. (in Chinese with English abstract)

Zhao, Q., Poulson, S. R., Sumaila, D. O. S., Dynes, J. J., McBeth, J. M. \& Y. Yang, 2016: Iron-bound organic carbon in forest soils: quantification and characterization.- Biogeosciences Discussions, 13, 47774788.

Zhou, X., Chen, C., Wang, Y., Smaill, S. \& P. Clinton, 2013: Warming rather than increased precipitation increases soil recalcitrant organic carbon in a semiarid grassland after 6 years of treatments-. PLOS ONE, 8, e53761.

Zupan Hajna, N., 1992: Mineral composition of mechanical sediments from some parts on Slovenian karst.Acta Carsologica, 21, 115-130. 